KAPL-2146

AEC Research and Development Report

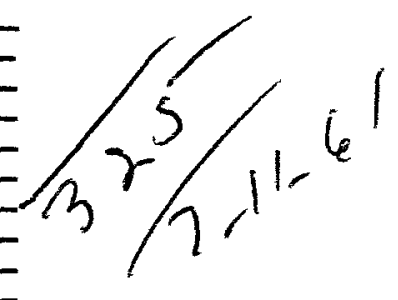

\title{
Application of the Ewing Equation for Cal- culating Thermal Conductivity from Electrical Conductivity
}

\author{
A. E. Powers \\ April 7, 1961
}

Operated for the

United States Atomic

Energy Commission by

GENERAL ELECTRIC 


\section{DISCLAIMER}

This report was prepared as an account of work sponsored by an agency of the United States Government. Neither the United States Government nor any agency Thereof, nor any of their employees, makes any warranty, express or implied, or assumes any legal liability or responsibility for the accuracy, completeness, or usefulness of any information, apparatus, product, or process disclosed, or represents that its use would not infringe privately owned rights. Reference herein to any specific commercial product, process, or service by trade name, trademark, manufacturer, or otherwise does not necessarily constitute or imply its endorsement, recommendation, or favoring by the United States Government or any agency thereof. The views and opinions of authors expressed herein do not necessarily state or reflect those of the United States Government or any agency thereof. 


\section{DISCLAIMER}

Portions of this document may be illegible in electronic image products. Images are produced from the best available original document. 
UNCLASS IF IED

\author{
KAPI-2146 \\ UC-25, Metals, Ceramics, \\ and Materials \\ (TID-4500, 16th Edition)
}

\title{
APPLICATION OF THE EWING EQUATION FOR CALCULATING THERMAL CONDUCTIVITY FROM ELECTRICAL CONDUCTIVITY
}

A. E. Powers

April 7, 1961

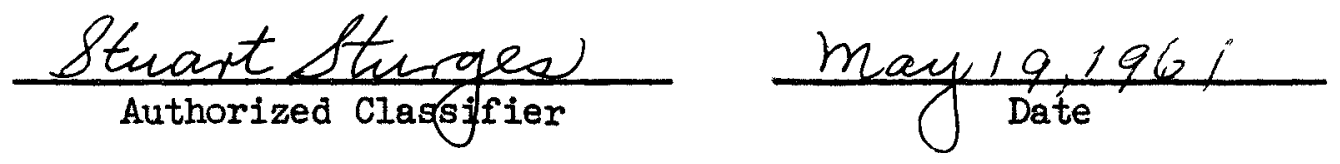

\author{
Knolls Atomic Power Laboratory \\ General Electric Company \\ Schenectady, New York \\ Operated for the \\ United States Atomic Energy Commission \\ Contract No. W-31-109 Eng-52
}


UNCIASSIF IED

LEGAL NOTICE

This report was prepared as an account of Governmentsponsored work. Neither the United States, nor the Commission, nor any person acting on behalf of the Commission:

A. Makes any warranty or representation, expressed or implied, with respect to the accuracy, completeness, or usefulness of the information contained in this report, or that the use of any information, apparatus, method, or process disclosed in this report may not infringe privately owned rights; or

B. Assumes any liabilities with respect to the use of, or for damages resulting from the use of any information, apparatus, method, or process disclosed in this report.

As used in the above, "person acting on behalf of the Commission" includes any employee or contractor of the Commission, or employee of such contractor, to the extent that such employee or contractor of the Camission, or employee of such contractor prepares, disseminates, or provides access to, any information pursuant to his employment or contract with the Commission, or his employment with such contractor.

\section{Printed in USA. Price .50 cents. Avallable from the Office of Technical Services, Department of Commerce, Washington 25, D. C.}




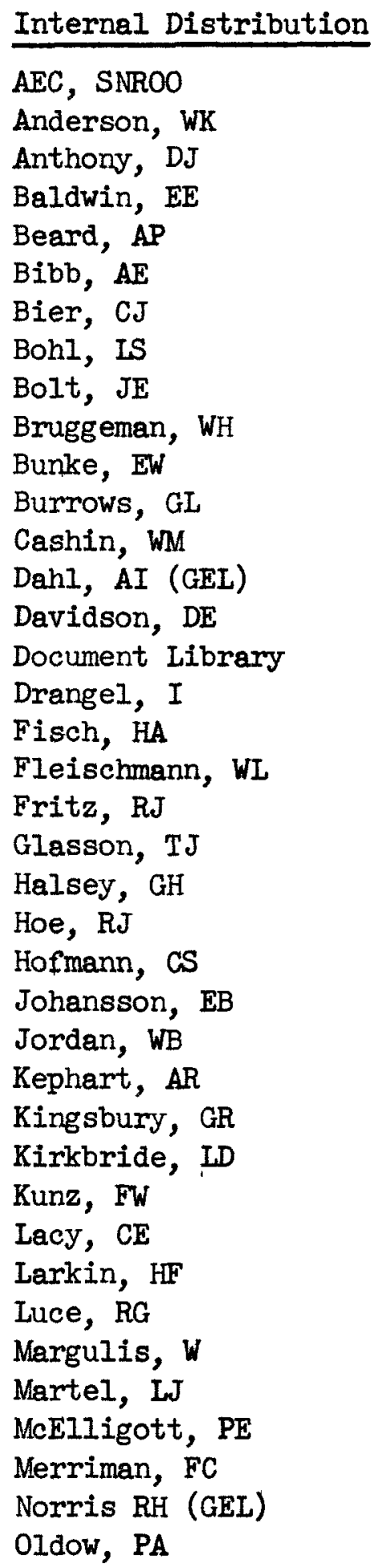

\section{KAPL-2146 \\ UC-25, Metals, Ceramics and Materials (TID-4500 16th edition) \\ No. of Copies}


KAPL-2146

Internal Distribution (continued)

No. of Copies

Plant, WR

Powers, $\mathrm{AE}$

10

Randall, $\mathrm{CH}$

1

Savidge, RE

Schmidt, CJ/TIG File

1

Seymour, WE

Sims, CT (M and P Lab, IST $-G$ Dept)

Technical Publications (OTIE)

Thomas, HA

Townsend, RG

1

Trott, BD

Wisnyi, LG

1

Wollam, JS

External Distribution

Aberdeen Proving Ground

Aerojet-General Corporation

Aerojet-General Nucleonics

AFPR, Boeing, Seattle

$A F P R$, Lockhead, Marietta

ANP Project Office, Convair, Fort Worth

Alco Products, Inc.

Allis-Chalmers Manufacturing Company

Allis-Chalmers Manufacturing Company, Washington I

Allison Division - GMC

Argonne National Laboratory

Armour Research Foundation

Army Ballistic Missile Agency

AEC Scientific Representative, Belgium

AEC Scientific Representative, France

AEC Scientific Representative, Japan

Atomic Energy Commission, Washington

Atomic Energy of Canada Limited

Atomics International

Babcock and Wilcox Company

Battelle Memorial Institute

Attn: H. W. Russell

Beryllium Corporation

Bridgeport Brass Company

Bridgeport Brass Company, Adrian

1

Brookhaven National Laboratory

Brush Beryllium Company 
KAPL-2146

External Distribution (continued)

No. of Copies

Bureau of Mines, Albany

1

Bureau of Ships (Code 1500) 1

Carborundum Company 1

Chicago Operations Office 3

Chicago Patent Group 1

Clevite Corporation 1

Combustion Engineering, Inc. 1

Combustion Engineering, Inc. (NRD) 1

Convair-General Dynamics Corporation, San Diego 1

Defence Research Member 1

Denver Research Institute 1

Department of the Army, G-2 2

Dow Chemical Company (Rocky Flats) 1

duPont Company, Aiken 4

duPont Company, Wilmington 1

Frankford Arsenal 1

Franklin Institute of Pennsylvania

General Atomic Division 2

General Electric Company (ANPD) 2

General Electric Company, Richland 6

General Electric Company, St. Petersburg 1

General Nuclear Engineering Corporation 1

Glasstone, Samuel 1

Goodyear Atomic Corporation 1

Grand Junction Operations Office 1

Iowa State University 2

Jet Propulsion Laboratory 2

Johns Hopkins University (ORO) 1

Ios Alamos Scientific Laboratory 3

Los Alamos Scientific Laboratory (Sesonske) 1

$M$ \& C Nuclear, Inc.

Mallinckrodt Chemical Works 2

Maritime Administration 1

Martin Company 1

Mound Laboratory 1

NASA Lewis Research Center 1

National Bureau of Standards 2

National Bureau of Standards (Library)

National Carbon Company 1

National Lead Company of Ohio 2

Naval Research Laboratory 3

New Brunswick Area Office 
External Distribution (continued)

KAPL-2146

New York Operations Office

No. of Copies

Northern Research and Engineering Corporation

Nuclear Development Corporation of America

Nuclear Materials and Equipment Corporation

Nuclear Metals, Inc.

Oak Ridge Institute of Nuclear Studies

Office of Naval Research

Office of Naval Research (Code 422)

Olin Mathieson Chemical Corporation

Ordnance Materials Research Office

Ordnance Tank-Automotive Command

Patent Branch, Washington

Phillips Petroleum Company (NRTS)

Picatinny Arsenal

Power Reactor Development Company

Pratt and Whitney Aircraft Division

Rensselaer Polytechnic Institute

Sandia Corporation, Albuquerque

Stevens Institute of Technology (Comstock)

Sylvania Electric Products, Inc.

Technical Research Group

Tennessee Valley Authority

Union Carbide Metals Company

Union Carbide Nuclear Company (ORGDP)

Union Carbide Nuclear Company (ORNL)

Union Carbide Nuclear Company (Paducah Plant)

USAF Project RAND

U.S. Geological Survey, Denver

U.S. Geological Survey, Menlo Park

U.S. Geological Survey, Washington

U.S. Naval Postgraduate School

U.S. Patent Office

University of California, Berkeley

University of California, Livermore

University of Puerto Rico

Watertown Arsenal

Westinghouse Bettis Atomic Power Laboratory

Westinghouse Electric Corporation

Wright Air Development Division

Yankee Atomic Electric Company

Office of Technical Information Extension

Office of Technical Services, Washington 


\section{CONTENTS}

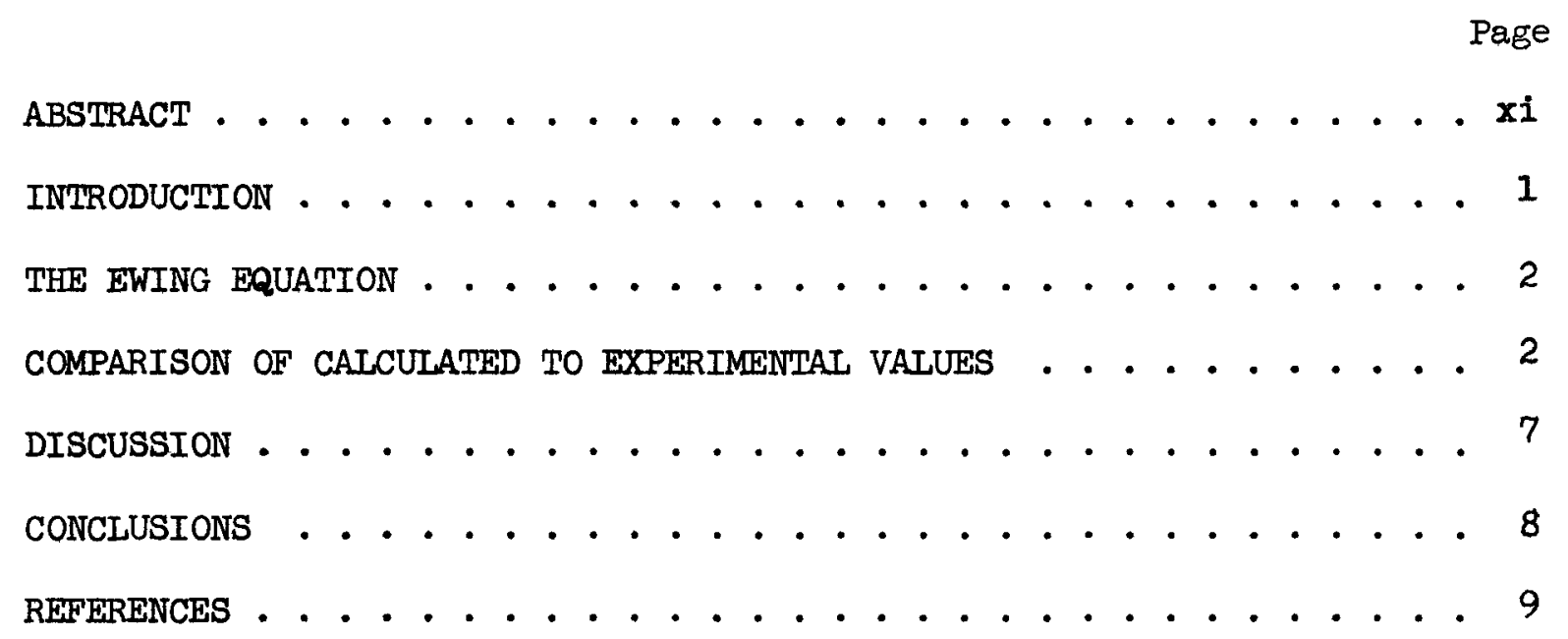




\section{ILUUSTRATIONS}

Number

Title

$\underline{\text { Page }}$

1 Electrical Resistivity of Alloys (Ka-42174)........3

2 Thermal Conductivity of Zircaloy-2 and -4 Determined Experimentally and Calculated from Electrical Resistance $(\mathrm{KS}-42175)$. . . . . . . . . . . . . 4 4

3 Thermal Conductivity of HSZA Determined Experimentally and Calculated from Electrical Resistance (KS-42176). . . . 4

4 Thermal Conductivity of $\mathrm{Nb}+5.5 \mathrm{w} / \mathrm{O} \mathrm{V}$ Determined Experimentally and Calculated from Electrical Resistance (KS-42I77)................... 5

5 Thermal Conductivity of Inconel Determined Experimentally and Calculated from Electrical Resistance (KS-42178). . . 5

6 Thermal Conductivity of 18-8 stainless Steel Determined Experimentally and Calculated from Electrical Resistance (KS-42179). . . . . . . . . . . . . . 6

7 Thermal Conductivity of $\mathrm{Na}-78 \mathrm{w} / 0 \mathrm{~K}$ Determined Experimentally and Calculated from Electrical Resistance (KS-42180) 6

TABLF

Number

Title

$\underline{\text { Page }}$

1 Composition of 'Zirealoys, HSZA, and Niobium +5.5

Vanadiun ................. 3 
-

-

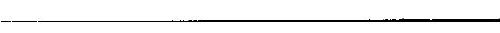




\begin{abstract}
The usefulness of the Ewing equation for calculating the thermal conductivity of reactor metals and alloys from electrical resistance, specific heat, density, and atomic weight has been investigated. The alloys investigated were Zircaloy-2, HSZA, $\mathrm{Nb}+5.5 \mathrm{w} / \mathrm{O} \mathrm{V}$, Inconel, 18-8 stainless steel, and eutectic NaK. The Ewing equation was found to give calculated values with a degree of confidence similar to that of actual measured values.
\end{abstract}


APPLICATION OF THE EWING EQUATION FOR CALCULATING THERMAL CONDUCTIVITY FROM ELECTRICAL CONDUCTIVITY

$$
\text { A. E. Powers }
$$

\section{INPRODUCTION}

Knowledge of accurate values for thermal conductivity of materials is extremely important in the engineering design of nuclear reactors. Fortunately, methods for calculating the over-all conductivity of dis persion materials are well developed mathematically $\mathrm{y}^{2}$, , but the calculated conductivity thus derived is accurate only to the extent thet the conductivity values for the individual component materials are precisely determined.

The experimental determination of thermal conductivity is a difficult and often an unsatisfactory undertaking, as is evidenced by the scarcity of such data and the variance in data orlginating from different apparatus and laboratories.

For many years theoretical and experimental considerations have shown a correspondence between thermal and electrical conductivity. This correspondence was one of the prime considerations during the ploneer developments in the modern theory of metals. Wledemann and Franz first pointed out, in 1853, that the ratio of the two conduçtivIties, $K / \sigma$, is falrly constant for all metals at room temperature ${ }^{3}$. Loreptz, in 1881 , then determined that $K / \sigma$ is proportional to temperature 4 , and, in 1900 , Drude ${ }^{5}$ showed that the Lorentz constant $K / O T=L=$ $3\left(k_{0} / e\right)^{2}$, where $k_{0}$ is the Boltzmann constant and $e$ is the electron charge. A further development of the electron theory of metals by Sommerfeld in 1928 using Fermi-Dirac statistics showed the constant to be $\frac{\pi^{2}}{3} \quad\left(\frac{k_{0}}{e}\right)^{2}=2.45 \times 10^{-8}$ when the units are expressed in the cgs system.

Although thermal conductivity in metals is largely electronic, some of the heat is conducted by the atomic lattice. An approximate relation is therefore

$$
\mathrm{K}=\mathrm{L} \sigma \mathrm{T}+\mathrm{k}
$$

where the term $\mathrm{L} \sigma \mathrm{T}$ is considered the electronic contribution and $\mathrm{k}$ is the lattice contribution. The constants $L$ and $k$ vary from metal to metal and with temperature. Therefore, the above relation is not of mach use in calculating thermal conductivity if only electrical conductivity is known, since $L$ and $k$ are also unknown. Occasionally, investigators have attempted to devise an equation for thermal conductivity based on the physical properties of the metal and related to Equation 1. The most recent, and perhaps the most successful, is the semi-empirical equation of Ewing, Walker, Grand, and Miller of the U.S. Naval Research Laboratory.7 
THE EWING EQUATION

Ewing, et al., correlated the thermal and electrical conductivities of 140 metals and alloys, both liquid and solid, developing the equation

$$
K=2.61 \times 10^{-8}\left(\frac{T}{\rho}\right)-2 \times 10^{-17}\left(\frac{T}{\rho}\right)^{2} \frac{1}{C_{p} d}+97 \frac{C_{p} d^{2}}{M T}
$$

where $\mathrm{K}=$ thermal conductivity in watts $/ \mathrm{cm}^{2} / \mathrm{cm} /{ }^{\circ} \mathrm{C}$.

$\rho=$ electrical resistance in ohm-cm

$\mathrm{C}_{\mathrm{p}}=$ specific heat in $\mathrm{cal} / \mathrm{gm},{ }^{\circ} \mathrm{C}$

$\mathrm{d}=$ density in $\mathrm{gm} / \mathrm{cc}$

$\mathrm{M}=$ average atomic or molecular weight .

Ewing et al. found the mean deviation for liquid metals to be $12 \%$ and for solid alloys less than $5 \%$. The equation has also been used for determining the degree of association of organic liquids with a fair degree of success.

The relation is an expansion of $K=L \sigma T+k$ with the Lorentz constant equal to $2.61 \times 10^{-8}$ rather than the theoretical $2.45 \times 10^{-8}$. The second term is a slight correction to the electronic component and the third term is considered to be related to the lattice component. The third term implies that atomic conduction at unit gradient is directly proportional to the energy difference across a centimeter cube, directly proportional to the number of ions per centimeter cube, and inversely proportional to the absolute temperature.

COMPARISON OF CALCULATED TO EXPERIMENTAL VALUES

The metals involved in the Ewing calculation of thermal conductivity were Zircaloy-2, $\mathrm{Zr}+2.7 \mathrm{w} / 0 \mathrm{Sn}+2.0 \mathrm{w} / 0 \mathrm{Nb}$ (HSZA), $\mathrm{Nb}+5.5 \mathrm{w} / \mathrm{o} \mathrm{V}$, Inconel, Type 304 stainless steel, and NaK. The electrical resistivities are given in Figure 1 and the compositions of the Zircaloys, HSZA, and $\mathrm{Nb}$ $+5.5 \mathrm{w} / 0 \mathrm{~V}$ are given in Table 1 . Curves of experimental and calculated values of thermal conductivity are illustrated in Figures 2 through 7 . Sources of the data and the bibliographic reference numbers are enclosed in brackets on each figure.

There are two calculated curves in Figure 2 for Zircaloy, both using the same electrical resistance data. One is from the Ewing equation and the other is from an equation for zirconium-base alloys devised by Bing, Fink, and Thompson at the Battelle Memorial Institute. 10 Although the Ewing equation lies about $6 \%$ below the mean of the experimental curves, it agrees more closely with the experimental data than does the Bing equation. 
TABLE I

COMPOSITION OF ZIRCALOYS, HSZA, AND NIOBIUM + 5.5 VANADIUM

\begin{tabular}{|c|c|c|c|c|}
\hline & $\begin{array}{c}\text { Z1rcaloy }-2 \\
{\left[\mathrm{BM}^{8}\right]} \\
\end{array}$ & $\begin{array}{c}\text { Zircaloy } 4 \\
{\left[\mathrm{BMI}^{9}\right]} \\
\end{array}$ & $\begin{array}{c}\text { HSZA } \\
{\left[\mathrm{BMI}^{\mathrm{B}}\right]}\end{array}$ & $\begin{array}{c}\mathrm{Nb}+5.5 \mathrm{w} / \mathrm{o} \mathrm{V} \\
{\left[\mathrm{BMI}^{\mathrm{e}}\right]} \\
\end{array}$ \\
\hline Sn & 1.47 & 1.32 & 2.72 & \\
\hline $\mathrm{Nb}$ & & & 2.18 & \\
\hline $\mathrm{Fe}$ & 0.125 & 0.152 & 0.071 & \\
\hline $\mathrm{Cr}$ & 0.086 & 0.099 & 0.006 & \\
\hline $\mathrm{NI}$ & 0.056 & 0.001 & & \\
\hline V & & & & 5.54 \\
\hline $\mathrm{Ta}$ & & & & 0.052 \\
\hline$S 1$ & $51 \mathrm{ppm}$ & & $60 \mathrm{ppm}$ & \\
\hline Al & 38 ppm & & $34 \mathrm{ppm}$ & \\
\hline C & 65 ppm & $150 \mathrm{ppm}$ & $80 \mathrm{ppm}$ & $65 \mathrm{ppm}$ \\
\hline $\mathbf{N}$ & $45 \mathrm{ppm}$ & 36 ppm & 46 ppm & $160 \mathrm{ppm}$ \\
\hline 0 & 1489 ppm & $1380 \mathrm{ppm}$ & $1260 \mathrm{ppm}$ & $142 \mathrm{ppm}$ \\
\hline $\mathrm{H}$ & . 11 ppm & $30 \mathrm{ppm}$ & $6 \mathrm{ppm}$ & \\
\hline $\mathrm{Cu}$ & $20 \mathrm{ppm}$ & $20 \mathrm{ppm}$ & $40 \mathrm{ppm}$ & \\
\hline Hf & $<125 \mathrm{ppm}$ & $60 \mathrm{ppm}$ & 60 ppm & \\
\hline
\end{tabular}

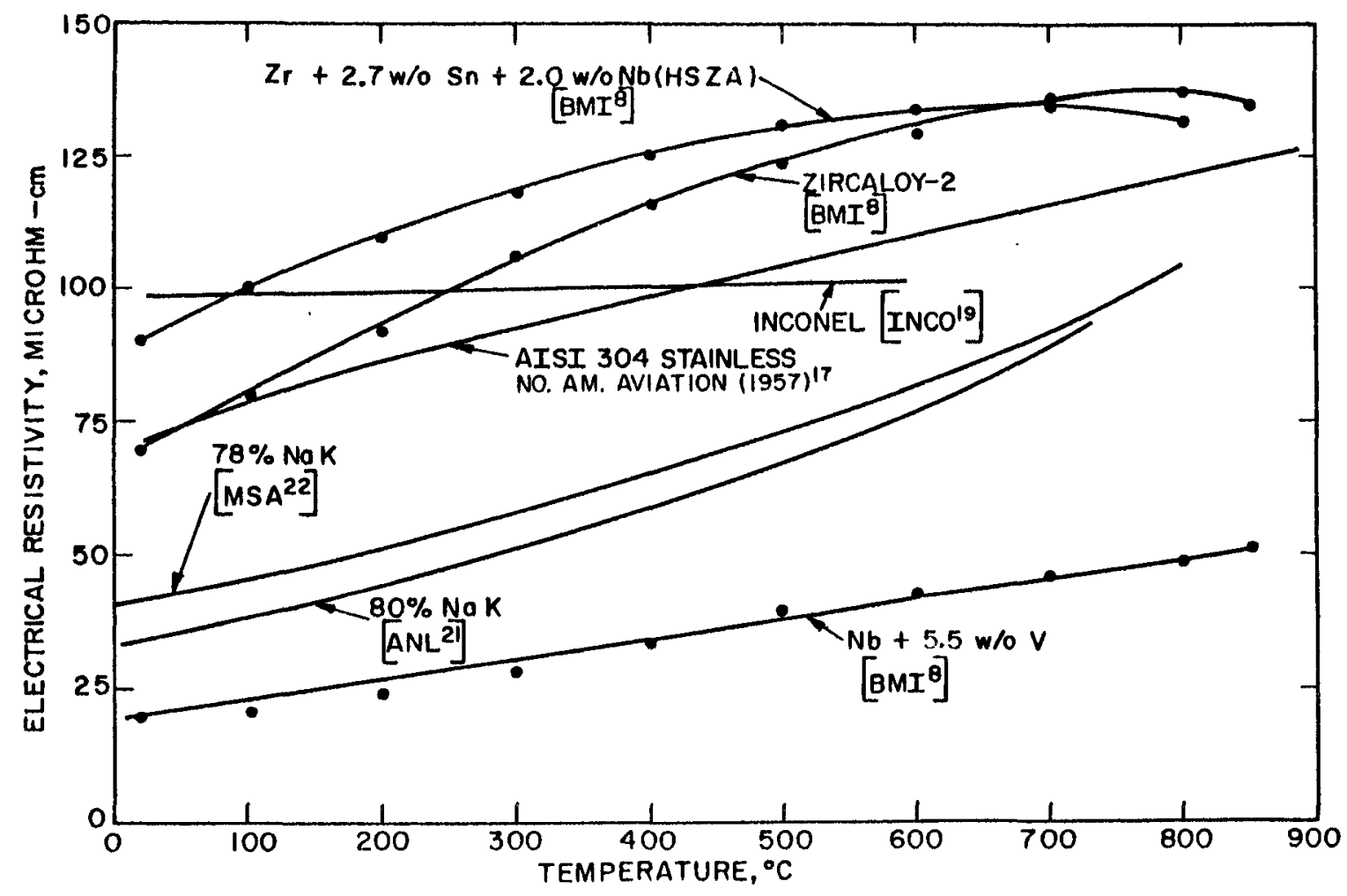

FIGURE 1. Electrical Resistivity of Alloys.

KS-42174 Unclassified 


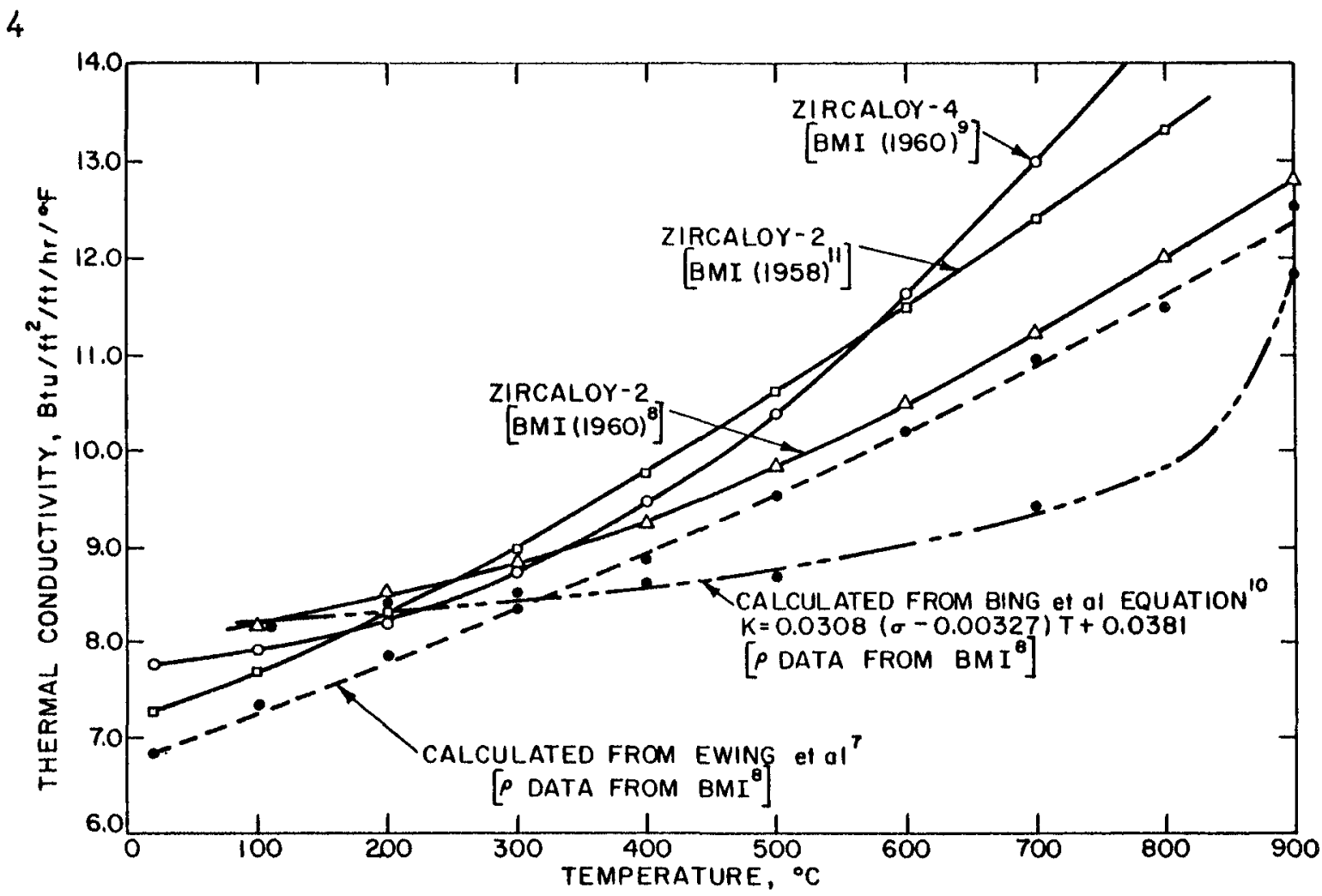

FIGURE 2. Thermal Conductivity of Zircaloy-2 and -4 Determined Experimentally and Calculated from Electrical Resistance.

KS-42175

Unclassified

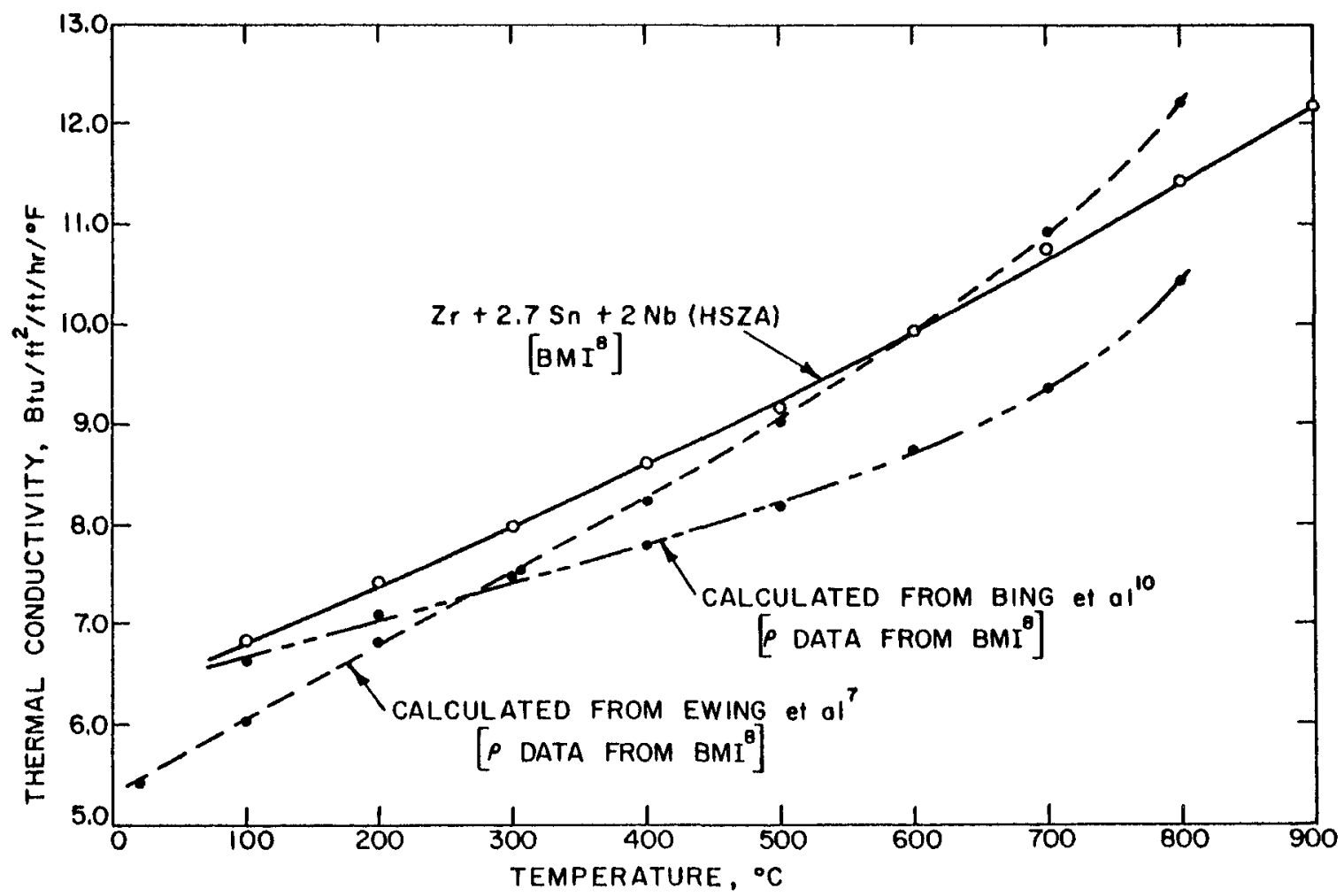

FIGURE 3. Thermal Conductivity of HSZA Determined Experimentally and Calculated from Electrical Resistance. 


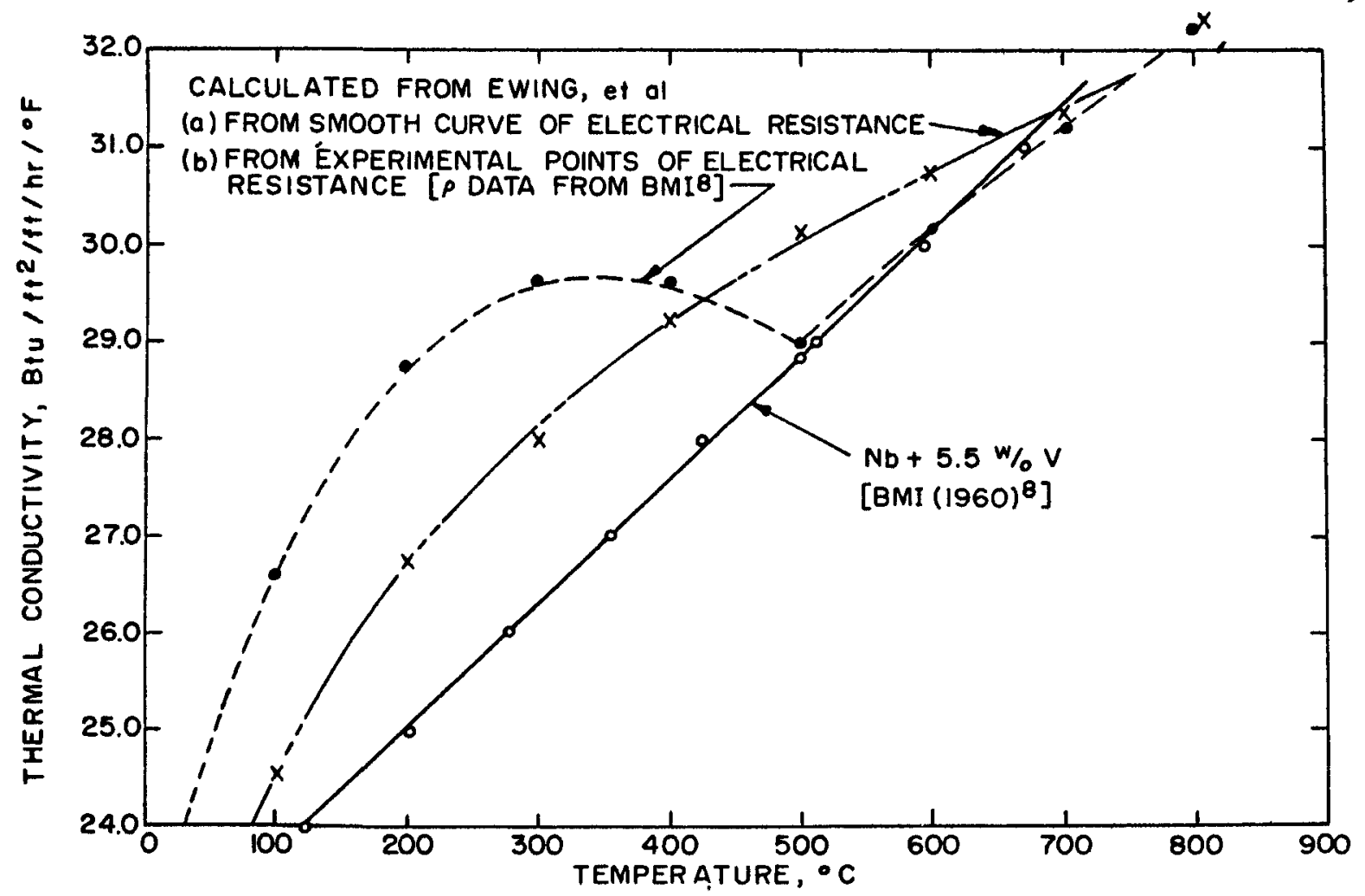

FIGURE 4. Thermal Conductivity of $\mathrm{Nb}+5.5 \mathrm{w} / \mathrm{O} \mathrm{V}$ Determined Experimentally and Calculated from Electrical Resistance.

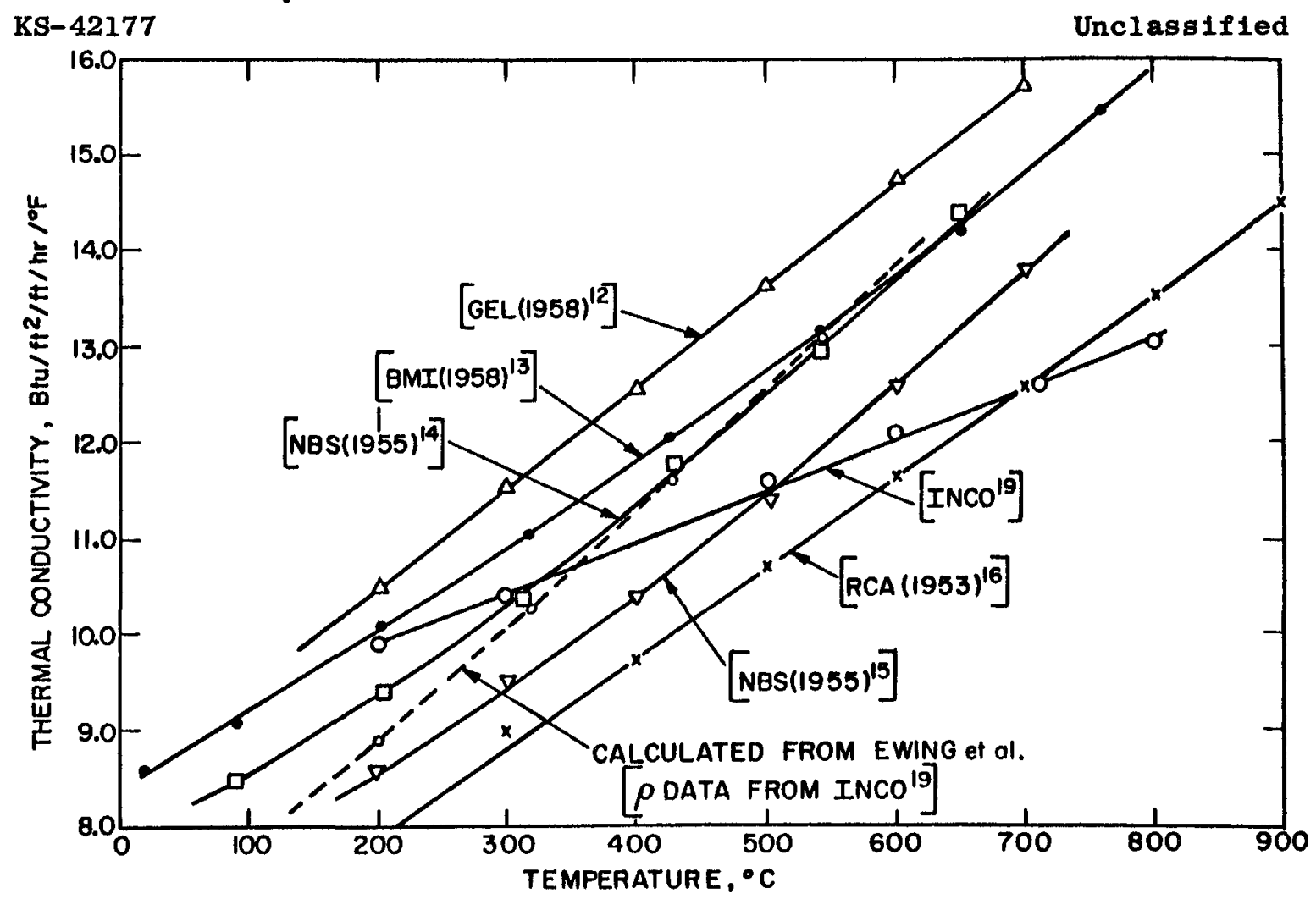

FIGURE 5. Thermal Conductivity of Inconel Determined Experimentally and Calculated from Electrical Resistance. 


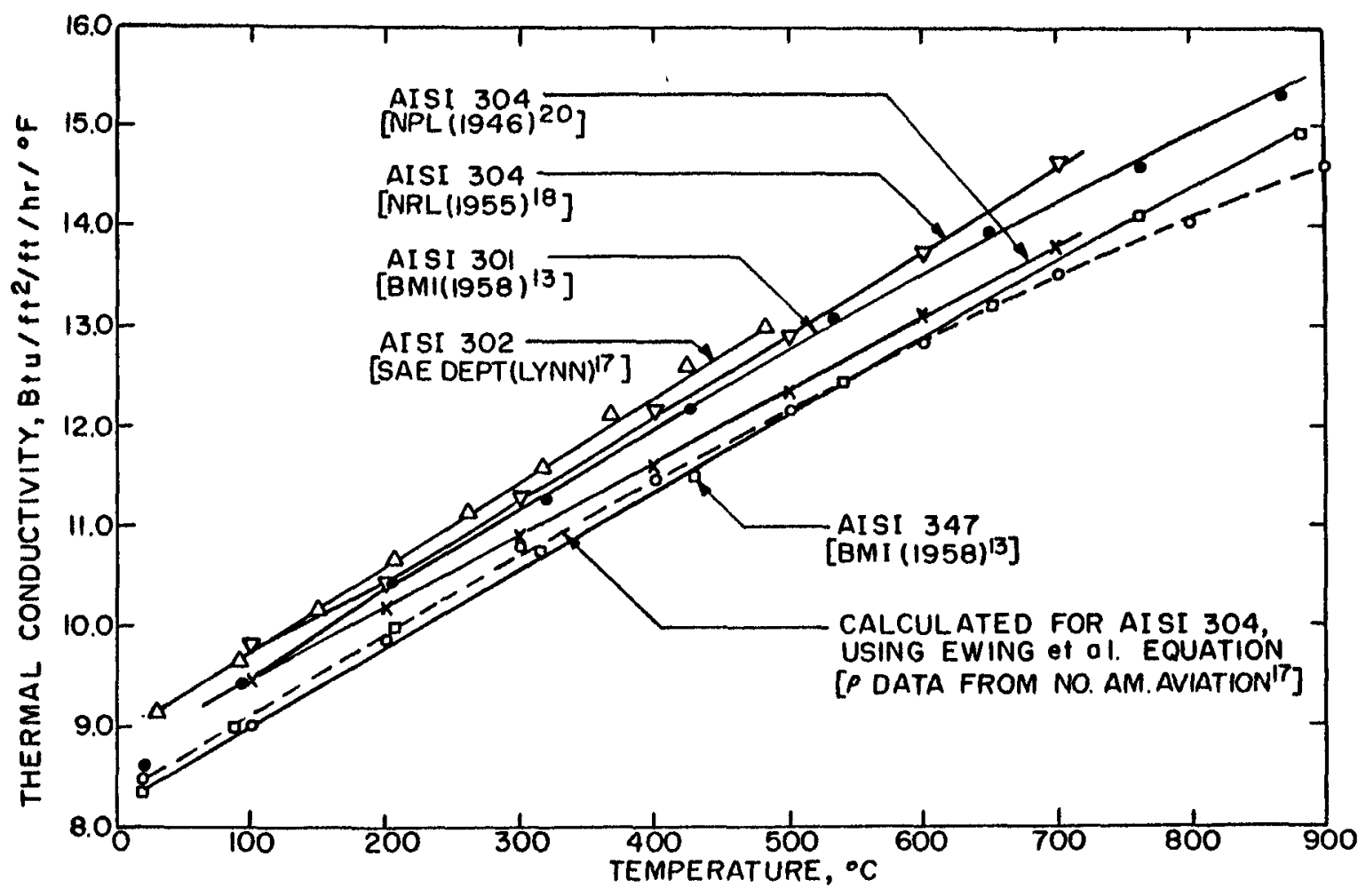

FIGURE 6. Thermal Conductivity of 18-8 Stainless Steel Determined

Experimentally and Calculated from Electrical Resistance. KS-42179

Unclassifled

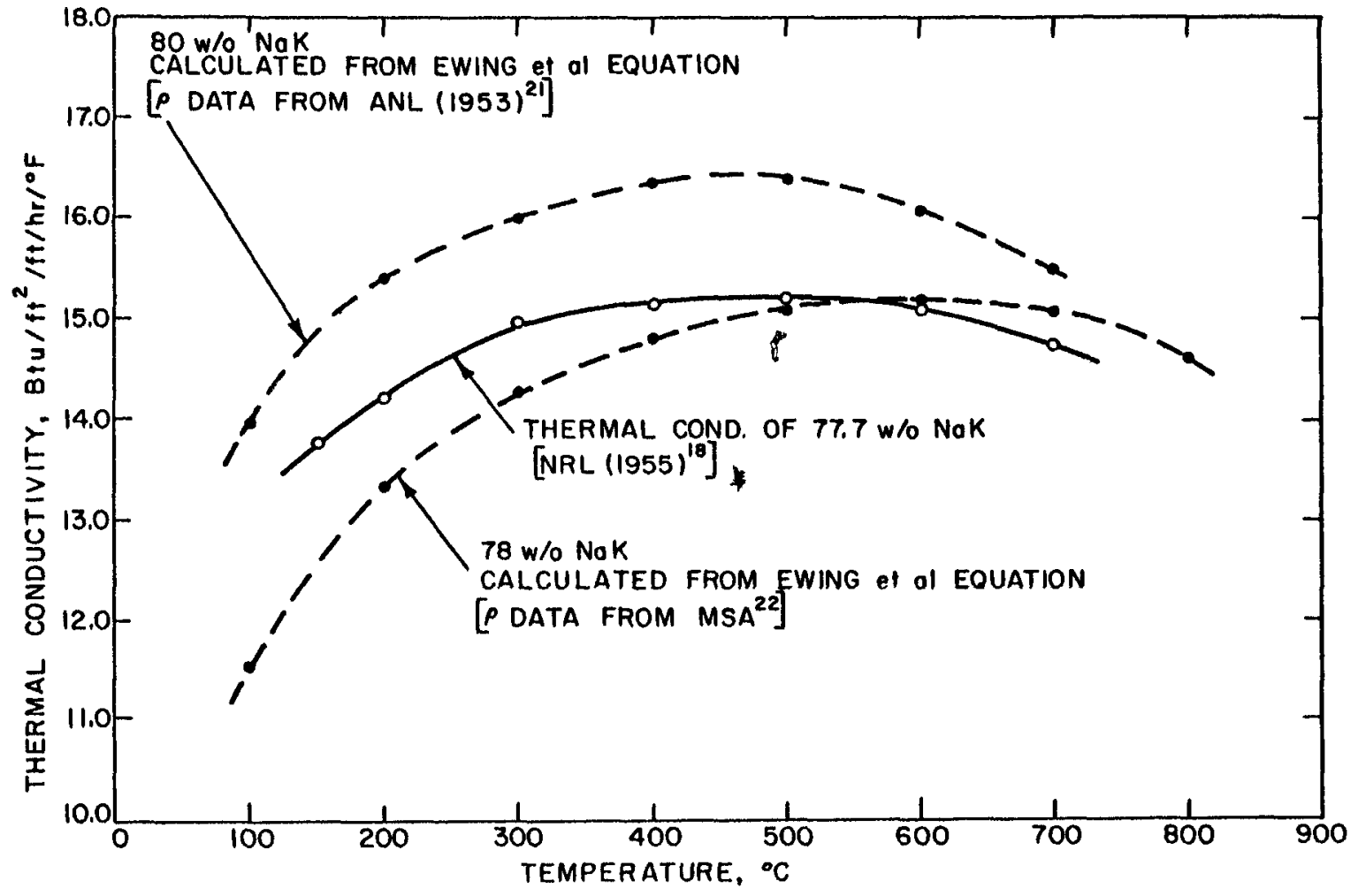

FIGURE 7. Thermal Conductivity of $\mathrm{Na}-78 \mathrm{w} / \mathrm{o} \mathrm{K}$ Determined Experimentally and Calculated from Electrical Resistance. 
Two calculated curves from the Bing and the Ewing equations are presented in Figure 3 for HSZA and again the Ewing equation is in closer agreement with the experimental data.

The data for $\mathrm{Nb}+5.5 \mathrm{~V}$ in Figure 4 illustrate: the difficulty presented by unsatisfactory electrical resistance values. The original data in Figure 1 possess. some scatter and when the actual data points are used in the calculation, curve $b$ of unsatisfactory nature results. Curve a was calculated from values taken from the smooth curve of electrical resistance rather than from the original data points. Curve a is still not in satisfactory conformance with the experimental curve:

For most metals and alloys, electrical conductivity data over a wide range of temperatures are more rare than thermal conductivity data. Only one set of data could be found for Zircaloy, HSZA, $\mathrm{Nb}+5.5 \mathrm{~V}$, Inconel, and 304 stainless steel. The single calculated curve in Figure 5 for Inconel lies approximately in the middle of a wide array of experimental curves.

The curves for several 18-8 stainless steels in Figure 6 are grouped together more closely than in the case of Inconel, and the single calculated curve lies along the lowest experimental curve.

Figure 7 presents two calculated curves and one experimental curve for a liquid metal -- eutectic Na-K alloy. It is obvious in this instance, as it has been for all the other alloys, that the congruity of calculated to experimental curves must depend, first of all, on the availability of accurate data for both thermal conductivity and electrical conductivity.

It is interesting to note in the calculations the proportion of lattice conductivity to total conductivity as indicated by the Ewing equation. The proportion of lattice conductivity diminishes as temperature increases. In Zircaloy-2, for example, it is $9 \%$ of the total at $20^{\circ} \mathrm{C}$ and $1.8 \%$ at $900^{\circ} \mathrm{C}$. At room temperature, the ratios are $11 \%$ for HSZA, $4 \%$ for $\mathrm{Nb}+5.5 \mathrm{~V}, 34 \%$ for Inconel, $27 \%$ for 304 stainless steel, and about $0.6 \%$ for eutectic NaK. These calculations may be inspected by the reader upon inquiry to the author.

\section{DISCUSSION}

The Ewing equation appears to be one of the best yet devised for calculating the thermal conductivity of solid and liquid metals and alloys from known values of electrical resistance, specific heat, density, and atomic weight. In most cases, by using the Ewing equation, thermal conductivity can be calculated with about the same degree of confidence as it can be measured directly. However, greater usefulness of this equation is hindered by the lack of accurate data on both electrical and thermal conductivity. With the availability of more accurate data, the Ewing equation could probably be modified to permit more precise calculations. For most metals, electricalconductivity data over a range of temperature are more rare than comparable thermal-conductivity data. 
The major use of the Ewing equation is in determining the approximate thermal conductivity and temperature coefficient for new alloys in a manner more economical than direct measurement. It can be of particular benefit in determining the directional thermal conductivity of dispersion-type materials. The applicability of this equation to nonmetallic materials has not been tested, although it contains a term for lattice conduction. Nevertheless, it might be particularly useful in determining anisotropy of conductivity in dispersion-type material. 1 But before engineering values of thermal conductivity in dispersion materials can be obtained from electrical resistance measurements, accurate determinations of both thermal and electrical conductivity must be available for the dispersion materials. The obtainment of such data, for the purpose of developing a WiedemannFranz type equation for application to metallic-nonmetallic dispersion systems, should be considered of high importance to the development of nuclear fuel materials.

\section{CONCLUSIONS}

The application of the Ewing equation should prove valuable in determining thermal conductivity from electrical resistance for reactor materials, particularly for composite and dispersion materials. There is an important need for accurate measurements of thermal and electrical conductivity on dispersion materials so that the Ewing-type equation may be developed for greater precision. 
REFERENCES

1. Powers, A.E. Conductivity in Aggregates. KAPL-2145, March 6, 1961.

2. Powers, A.E. Fundamentals of Thermal Conductivity at High Temperatures. KAPL-2143, ApriI 7, 1961.

3. Wiedemann, G. and R. Franz "The Thermal Conductivity of Metals", Ann. Physik, 89, 1853, pp. 497-531.

4. Lorentz, I. "The Conductivity of Metals for Heat and Electricity", Ann. Physik, 13, 1881, pp. 422-447.

5. Drude, P. "The Electron Theory of Metals", Ann. Physik, I, 1900, pp. $566-613$.

6. Sommerfeld, A. "The Electron Theory of Metals Based on Fermi Statistics", Z. Physik, 47, 1928, pp. 1-32 (I).

7. Ewing, c.T. et al. "Thermal Conductivity of Metals", Liquid Metals Technology, Chem. Eng. Progr. Symposium Ser., No. 20, 1957, pp. 19-24.

8. Deem, H.W., BMI. "Thermal and Electrical Conductivity of Zircaloy-2, HSZA, and Nb-6 V". A letter to A.P. Beard, KAPL, August 29, 1960.

9. Young, H.W., Bettis Atomic Power Laboratory (Westinghouse). Thermal Conductivity of Zirconium Alloys. (Letter to J. Hino, Bettis, July 22, 1960). WAPD-M-(RM) -3036 .

10. Bing, G., F.W. Fink, and H.B. Thompson. The Thermal and Electrical Conductivities of Zirconium and Its Alloys. BMI-65, April 16, 1951.

11. Lucks, C.F. and H.W. Deem. "Thermal Conductivity of Uranium and $\mathrm{UO}_{2}$ ", Progress Relating to Civilian Applications During June 1958. BMI-1273, July 1, 1958.

12. General Engineering Laboratory (General Electric Co., Schenectady, N.Y.). Data from Engineering Physics and Analysis Laboratory, GEL, provided by A.I. Dahl, in oral communication with author.

13. Lucks, C.F. and H.W. Deem. Thermal Properties of Thirteen Metals. Philadelphia: Am. Soc. Testing Materials, 1958. ASTM-STP-227.

14. O'Sullivan, W.J., Jr. "Some Thermal and Mechanical Properties of Inconel at High Temperatures for Use in Aerodynamic Heating Research", ASTM Proceedings, 55, 1955, pp. 757-64.

15. Richards, L.E. and H.E. Robinson. Thermal Conductivity of a Specimen of Incone1. NBS-4038, April 11, 1955. 
16. Silverman, I. "Thermal Conductivity Data Presented for Various Metals and Alloys Up to $900^{\circ} \mathrm{C} "$, J. Metals, 5, May, 1953, pp. 631-32.

17. Sachs, G. (ed.). Air Weapons Material Application Handbook: Metals and Alloys. ARDC-TR-59-66, December 1959.

18. Ewing, C.T. et al. "Thermal Conductivity of Mercury and Two SodiumPotassium Alloys", J. Phys. Chem., 59, June, 1955, pp. 524-28.

19. Intern. Nickel Co., Inc. Engineering Properties of Inconel. INCO Tech. Bull. T-7, September, 1959.

20. Am. Soc. Metals. Metals Handbook. Cleveland: ASM, 1948, p.314.

21. Drugas, P.G., I.R. Rehn, and W.D. Wilkinson. Resistivity of NaK. ANL-5115, October 2, 1953.

22. Rahiser, R.H. Electrical Resistivity of Sodium and Sodium-Potassium Alloys. Mine Safety Appliances Company, MSA-24, June 17, 1953. 